\title{
Comprehensive understandings in the shape of retromolar pad and its classification based on clinical application
}

\author{
Chan-Jin Park, Kyung-Ho Ko, Yoon-Hyuk Huh, Lee-Ra Cho* \\ Department of Prosthodontics and Research Institute of Oral Science, College of Dentistry, Gangneung-Wonju National University, \\ Gangneung, Republic of Korea
}

Retromolar pad is one of anatomical landmarks to use clinically for determining of specific occlusal plane level in edentulous patients and is inherently a soft tissue mass; located at the distal end of mandible and should be covered with denture. The shapes of retromolar pad show variability because it might be inevitable to be resultant forms from healing and remodeling process after the extraction of last molars. Considerations would be focused on those resultant shapes and classification with anatomical relationships and clinical significances. (J Dent Rehabil Appl Sci 2019;35(2):64-71)

Key words: retromolar pad; variability; shape; classification

\section{서론}

가철성 의치를 제작하는데 있어서 하악 잔존치조제(residual alveolar ridge)의 후방 말단에 위치한 연조직 덩어 리인 후구치삼각융기(retromolar pad)를 피개하는 것은 필수적으로 여겨진다. ${ }^{1}$ 후구치삼각융기가 존재하는 하악 후구치 영역의 구조물을 지칭하는 용어에 있어서 학자들 마다 범위를 규정하는 용어의 구분은 다소 혼용되거나 모호한 지칭으로 인해 명확한 구분을 할 필요가 있고, 후 구치삼각융기의 형태에 관한 연구된 문헌들은 거의 찾아 보기 힘들다. 본 문헌고찰에서는 후구치삼각융기가 존재 하는 후구치 영역에 대한 해부학적 지식 및 임상적 가치 와 형태적인 분류에 대해 정리해 보고자 하였다.

\section{문헌고찰}

후구치 영역의 소구조물 (small anatomical structures

*Correspondence to: Lee-Ra Cho

Professor, Department of Prosthodontics and Research Institute of Oral Science, College of Dentistry, Gangneung-Wonju National University, Jukheongil 7, Gangneung, 25457, Republic of Korea

Tel: +82-33-640-3153, Fax: +82-33-640-3103, E-mail: lila@gwnu.ac.kr

Received: May 8, 2019/Last Revision: May 22, 2019/Accepted: May 24, 2019 of retromolar region) 구분

Craddock$^{2}$ 은 후구치 영역의 미세 구조물들에 대해 5 가지로 구분할 것을 제안하였는데, 제 3 대구치 후방에 존 재하는 골 표면 구조인 후구치삼각(retromolar triangle), 후구치와(retromolar fossa)(Fig. 1)와 제3대구치 후방 연 조직 상의 구조인 후구치유두(retromolar papilla), 배형 태융기(pear-shaped pad), 후구치융기(retromolar pad) 가 그것이다(Fig. 2, 3). 후구치삼각(retromolar triangle) 은 치열궁의 연속선상에 위치하고 외측으로 하악지의 전 연(anterior border of mandibular ramus)이 시작되기 전 까지의 경계를 갖는 오목한 구조물로 흔히 제 3 대구치가 존재하면 명확하게 삼각형의 형태를 관찰할 수 있다. 후 구치와(retromolar fossa)는 치열궁의 연속선을 벗어나 외측으로 하악지의 전연이 시작되는데, 하악지의 전연이 시작되는 부위의 내측으로 형성된 난원형의 압흔(ovoid depression)을 일컫는다. 후구치유두(retromolar papilla)

CopyrightC 2019 The Korean Academy of Stomatognathic Function and Occlusion. (c) It is identical to Creative Commons Non-Commercial License. 


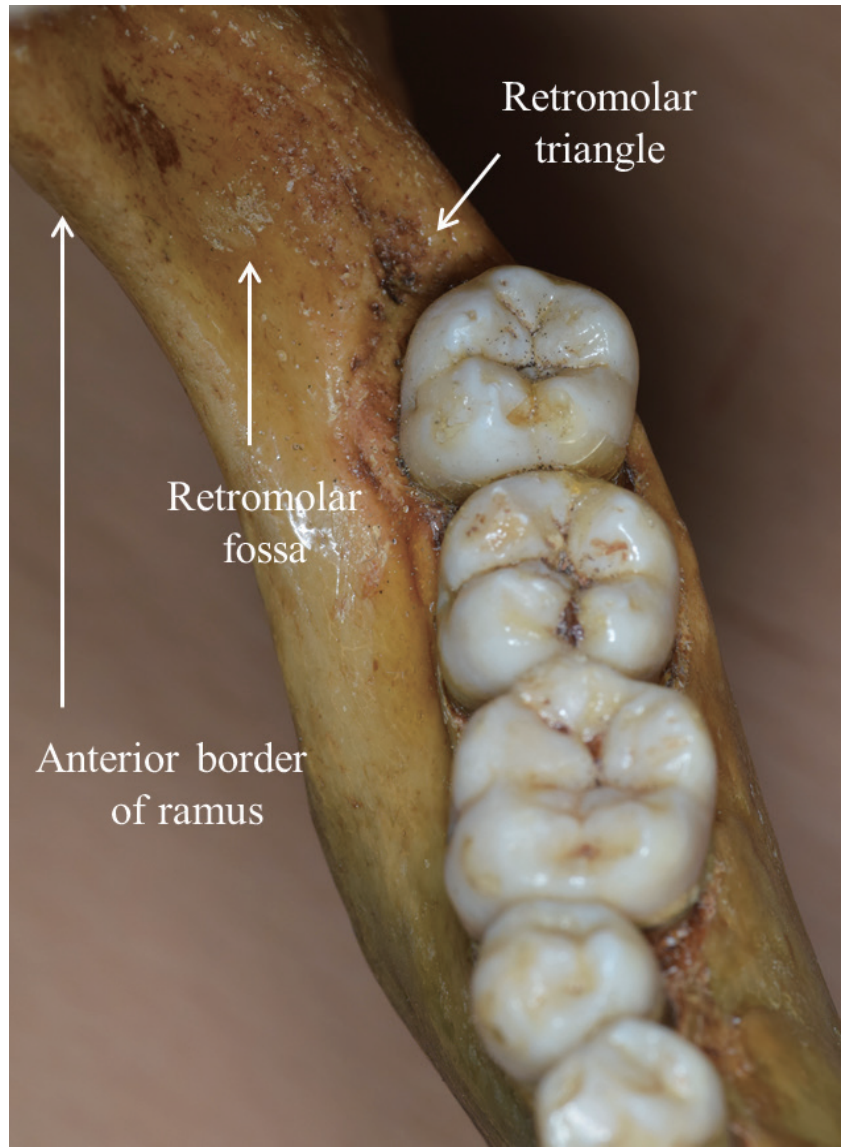

Fig. 1. Bony structures of retromolar region. Retromolar triangle is located behind a third molar and retromolar fossa, an ovoid depression, is deeper, more laterally placed and larger than the retromolar triangle. Unlikely the retromolar triangle, it can be palpated. Retromolar fossa is bounded laterally by the external oblique ridge and its continuation in the anterior border of the ascending ramus; medially it is bounded by the temporal crest and at a lower level by the buccal border of the small retromolar triangle.
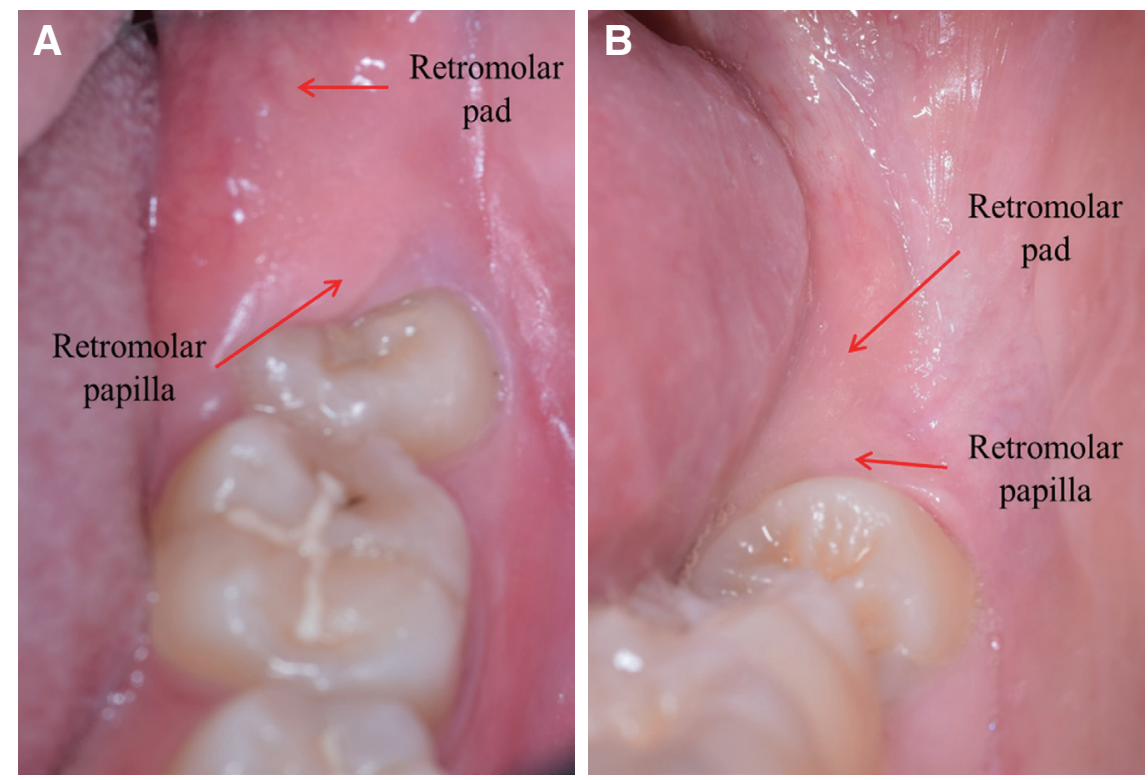

Fig. 2. Relationship between retromolar papilla and retromolar pad when a third molar is present. Directly overlying the base or mesial side of the bony retromolar triangle is the retromolar papilla, a small rolled or crescent-shaped elevation of the mucosa. Retromolar pad is posteriorly continuous with the pterygomandibular raphe. (A) The distal half of a third molar is partially covered with retromolar papilla. (B) Retromolar papilla is clearly located surrounding the distal surface of a third molar. 

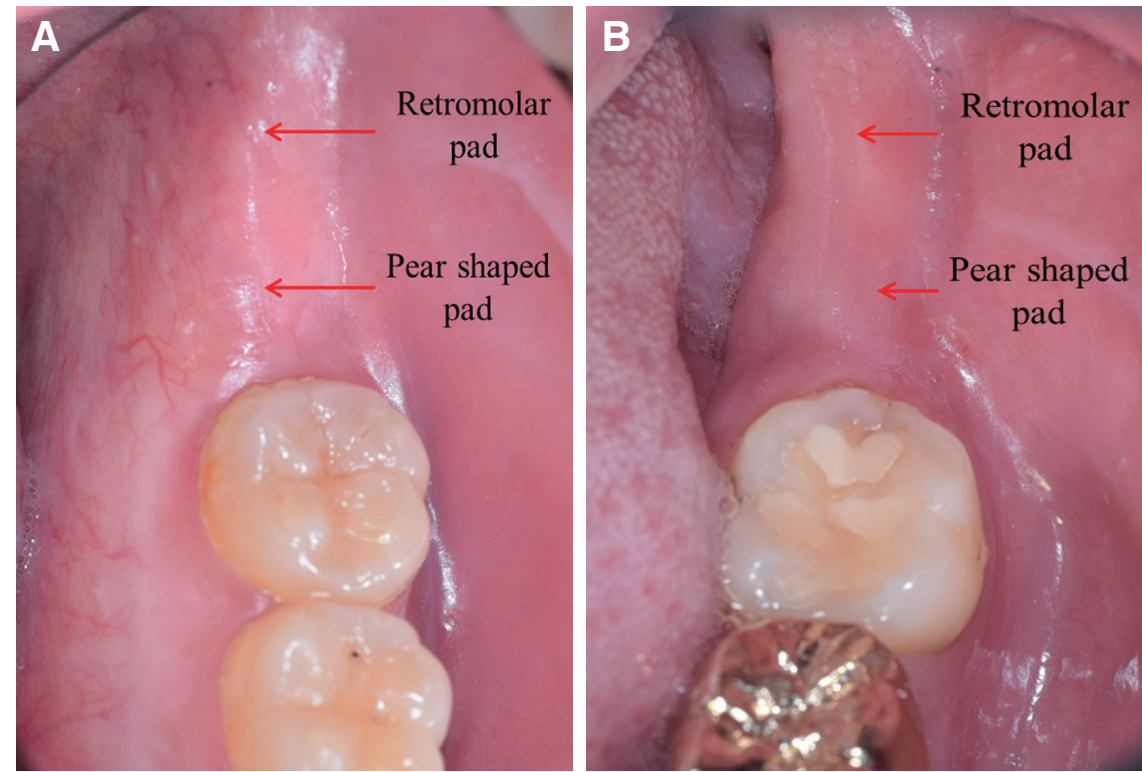

Fig. 3. Relationship between pear shaped pad and retromolar pad when a third molar is not present. After losing last molars, retromolar pad is anteriorly blended with a new elevation, so called, pear shaped pad. Pear shaped pad consists of fibrous tissue of the same kind as that forming the gingival mucosa, it is directly in line with the crest of the edentulous alveolar ridge, and it forms the distal termination of this residual structure. (A) An existed third molar was extracted and consecutively, soft tissue healing and bone remodeling process created the fusion with previously surrounding structures. (B) A third molar is congenitally missing. Relatively, smooth and long soft tissue continuity is shown behind a second molar.

는 정상적인 방향으로 맹출된 제3대구치의 치관을 둘 러싸고 있는 원심부 각화치은을 지칭하며, 배형태융기 (pear-shaped pad)는 제3대구치 발거 후 수축된 연조직 이 형성하여 후방으로 이행하는 각화치은부를 말한다. 또한, 후구치융기(retromolar pad)는 배형태융기에 연속 된 형태로 비각화점막부를 지칭하고 후방으로 익돌하악 봉선(pterygomandibular raphe)이 연속된다. 따라서, 후 구치 영역은 제 3 대구치가 존재하지 않거나 제3대구치를 발거하여 치유된 형태의 것에서 골표면 구조의 형태나 연 조직 구조의 형태에 있어서 상이함이 많음을 유추할 수 있다. 이는 Craddock이 당시의 용어사용에 있어서 학자 들 간에 많은 혼란이 있음을 지적하면서 후구치 영역을 지칭하는 다수 용어상의 구분을 다소 명확하게 한 것이 라 사료된다. 현재의 개념에서는 ${ }^{2}$ 의치 시술과 관련된 임 상적 중요성에 가치를 두어 후구치 영역의 미세구조를 따로 구분하지 아니하고 “후구치삼각융기(retromolar $\mathrm{pad})$ "로 통칭하며 이를 조직학적 특성에 따라 미세구조 상 구분할 때에는 전방부(anterior portion/Craddock의 pear-shaped pad)와 후방부(posterior portion/Craddock 의 retromolar pad)로 나누어 생각하게 되었다.

\section{후구치삼각융기의 해부조직학적 구조}

의치의 원심연장한계는 하악지와 협근(buccinator muscle), 상인두수축근(superior constrictor muscle)의 일부 근섬유로 구성된 익돌하악봉선(pterygomandibular raphe)에 의해 제한된다. 하악골의 악설골능선(mylohyoid ridge)에서 연장된 내사능선(internal oblique ridge) 과 협붕(buccal shelf) 외측에서 이어지는 외사능선(external oblique ridge)은 하악지의 전연에서 만나게 되어 급 격한 경사를 이루는데, 이와 같은 이유로 하악지의 전연 부위에 의치의 원심부가 접촉하게 되면 골을 뒤덮는 연조 직에 외상을 만드는 결과를 낳게 된다. 하악지의 전연 전 방에 위치하는 잔존치조제(residual alveolar ridge) 원심 부의 상방을 덮는 후구치삼각융기는 하방 골조직이 여러 근섬유 부착부로 기능하여 단단한 피질골로 이루어져 있 고 흡수에 저항하는 특성이 있다. ${ }^{2}$ 따라서, 의치는 부가 적인 지지를 얻을 수 있으며, 장기적인 피질골 흡수에 저 항성을 갖는 후구치삼각융기를 피개하는 것이 필수적으 로 여겨진다. 이와 같이, 후구치삼각융기는 하악 잔존치 조제의 후방 말단에 위치한 연조직 덩어리로, 주변부에서 
이어지는 근육섬유들을 포함하고 있다. 표면의 상피는 두 부분으로 구분할 수 있는데, 전방부는 제3대구치와 관련된 잔존각화치은상피로 이루어져 배형태융기(pear shaped pad)로 불리며, 후방부는 비각화점막상피로 이루 어져 있다. $\mathrm{McCrorie}^{3}$ 는 전방부와 후방부의 조직학적 관 찰결과에서 점액분비선(mucous glands)의 유무에 따라 구분할 수 있으며, 전방부일수록 깊은 $\operatorname{tag}$ 를 갖는 상피세 포층을 관찰할 수 있고 후방부일수록 이러한 경향은 사 라진다고 하였다. 또한, 전방부일수록 콜라겐섬유가 크 고 많이 관찰되며 불규칙적인 특성을 나타내고 후방부로 갈수록 규칙적인 배열을 보인다고 하였다. 또한, 후구치 삼각융기는 제 3 대구치 후방에 위치하는 삼각 형태의 연 조직 융기로 연조직 융기내에는 선조직, 협근 섬유, 상인 두수축근 섬유, 익돌하악봉선 섬유와 측두근(temporal muscle)의 힘줄 종말을 포함하고 있다. ${ }^{1}$ 이와 같은 해부 조직학적 특성을 고려하면, 의치 장착 후 변위를 최소화 할 목적으로 하악의치를 위한 변연형성 과정을 행하는데 있어서 하악의 개폐구를 환자에게 지시하여 해부조직학 적 특성에 따른 의치의 원심단의 형태를 결정하는 이론적 근거가 된다.

\section{잔존치조제 흡수와 후구치삼각융기}

하악에서 최후방 구치가 상실되면 연조직 하방의 치유 와 골개조가 일어나게 되고 흡수되면서 원심부에 존재하 던 기존의 후구치삼각융기와 융합하게 되어 ${ }^{4}$ 결과적으 로 잔존치조제, 부착근육과 이를 덮는 연조직이 하악무 치악 후구치삼각융기를 구성하게 된다. 제 3 대구치의 존 재유무와 존재 시 발거에 따른 후구치삼각융기 전방부의 골표면은 활발한 골개조가 일어나더라도 후방부는 제3 대구치 유무와 관계없이 존재하고 이의 하방에는 단단한 하악골 피질골판이 존재하여 골흡수에 저항도가 높은 특 성을 지닌다. 즉, 후구치삼각융기의 전방부는 골개조 결 과와 이를 덮는 단단한 부착치은부에 의해, 후방부는 하 방의 단단한 피질골판에 의해 상대적인 안정성을 갖는 다. 이와 같은 이유로, Wright ${ }^{5}$ 는 과도하게 진행된 골흡 수를 가진 무치악환자에서도 후구치삼각융기는 안정적 인 후방부 참고부위임을 주장하였다.

Pistrokovski 등 ${ }^{6}$ 도 75 명의 무치악 하악골에서 후구 치삼각융기 하방의 골조직을 후구치 능선(retromolar ridge)이라 언급하면서 후구치 능선의 설측 부위는 악설 골능선으로부터 연장되는 내사능선에 의해, 협측 부위는
협붕으로부터 연장되는 외사능선에 의해 이루어지는데 각 능선부위에 근섬유의 부착이 이루어져 있어 잔존치조 제의 흡수가 과도하게 진행되더라도 후구치능선은 흡수 에 저항하는 구조임을 확인하였다.

\section{후구치삼각융기의 임상적 가치}

하악의치상은 적절한 폐쇄와 의치상의 움직임을 최소 화함으로써 의치를 안정화시키기 위한 목적으로 후구치 삼각융기를 덮어야만 한다. ${ }^{1}$ 하악의치는 설측변연의 형 태가 악설골근(mylohyoid muscle)의 수축에 따른 형태 를 반영해야 하고 악설골능선의 후방부인 후악설골영역 (retromylohyoid area or fossa)까지 주행하는 형태여야 한다. 이를 통해 혀의 측방이 의치 설측변연의 연마면에 얹히는 형태로 의치가 제작되어야 강한 혀근육의 움직임 에 대해 하악의치의 안정성(stability)을 획득할 수 있다. 후구치삼각융기까지 의치상의 변연이 연장되지 않는다 면 후악설골영역까지 의치상의 변연연장이 어려워지며, 연장이 가능하다 하더라도 변연봉쇄효과를 얻기가 곤 란해지는 까닭에 궁극적으로는 하악의치의 안정성이 현 저하게 떨어지는 결과를 초래하게 된다. 부가적으로 후 구치삼각융기 각화치은부에 대해 약간의 지지를 기대할 수 있으며, 이와 같은 점은 심하게 흡수가 진행된 잔존치 조제를 갖는 하악의치 제작에 있어서 일차 지지영역(primary stress bearing area)으로서 협붕이 제 기능을 기대 하기 어려운 상황에서 더욱 부각된다. 따라서, 주위 근육 과 조화를 통한 하악의치의 안정성과 유지(retention), 추 가적인 지지(support)를 얻기 위한 목적으로 후구치삼각 융기까지 의치상의 연장은 정당화될 수 있다. 이와 더불 어, 무치악환자에게서 교합평면을 결정하기 위한 안정적 인 참고부위로 사용되어 치아 발거 후에 교합평면과 관 계되는 중요한 임상적 역할을 한다. Ismail 등과 Wright ${ }^{8}$ 는 교합평면이 후구치삼각융기의 일정 높이 지점과 일치 하는 경향이 있다고 주장하였다. 이와 같이, 후구치삼각 융기는 가철성 의치를 제작하기 위한 중요한 참고부위이 지만, 무치악환자의 하악은 골, 점막 및 부착근육의 형태 와 형태, 크기, 분포 등이 상이하기에 교합평면을 위한 참 고부위로 신뢰할 만한가라는 점에 대해 의문스럽다는 주 장도 있다. ${ }^{9-11}$ Pendleton $^{10}$ 은 후구치삼각융기와 하방의 골을 포함하는 시상절단면 시편의 조직학적 연구에서 후 구치삼각융기 하방의 골조직에는 근섬유 다발이 부착함 과 동시에 후구치삼각융기 내에는 점액분비선으로 가득 
채워져 있고, 특히 후방부는 느슨한 결합조직(loose connective tissue)이 풍부하게 존재하고 있다고 하면서 후구 치삼각융기 부위를 “area of variability”라고 주장하였 다.

\section{후구치삼각융기와 교합평면 설정 기준}

인체가 갖는 교합평면은 각 개인 특성에 맞게 주위 근 육계, 근신경조절계에 조화롭게 위치한 치아배열의 결과 이며, 관계되는 모든 조건들은 안정적이고 유지력이 있 는 의치제작에도 동일하게 적용되어야 할 것이다. 자연 치를 상실한 무치악환자마다 어떻게 하면 최적의 교합 평면을 설정할 수 있는가에 대한 문제는 자연치열과 해 부학적 지표들간의 관계를 밝히고자 한 노력에서 기초 하였다. ${ }^{12}$ 하악에서 이용되는 해부학적 지표들로 후구 치삼각융기, ${ }^{7,13-19}$ 혀의 측방경계, ${ }^{20-22}$ 협근구(buccinators groove) ${ }^{17-19}$ 그리고 구순각(commissure of the lips)이 ${ }^{17,18}$ 이용되고 있다.

Boucher ${ }^{13}$ 와 $\mathrm{Hall}^{14}$ 은 무치악환자를 위한 하악교합평 면의 기준을 후구치삼각융기의 근심 $2 / 3$ 높이에 설정하 는 것을 추천한 반면, Rahn 등 ${ }^{15}$ 은 $1 / 2$ 높이를 초과하지 않는 것을 주장하였고, Engelmeier는 ${ }^{16}$ 시상면에서 후구 치삼각융기의 상방 $1 / 3$ 과 중앙 $1 / 3$ 의 경계지점으로 결정 하였다. Gupta 등 ${ }^{17}$ 은 금속자를 이용하여 하악견치정으 로부터 제 2 대구치 혹은 제 3 대구치 교두정을 잇는 선을 가정했을 때, 대부분의 경우에서 후구치삼각융기의 중앙 $1 / 3$ 에 일치한다고 주장하였다. 측정값을 이용한 연구들 로, Lunquist 등 ${ }^{18}$ 은 16 게이지 철사를 이용하여 하악 견치 정에서 제 2 대구치 혹은 제 3 대구치의 설측원심교두를 연 결한 직선을 설정하고 이의 수평연장선이 후구치삼각융 기에 닿는 지점을 측정한 연구에서 약 $75 \%$ 연구대상자 에서 후구치삼각융기의 하방 $1 / 2$ 에 위치함을 관찰하였 다. 후구치삼각융기를 3 가지 높이로 구분하고 Lunquist 등의 연구와 같은 방법으로 관찰한 Shigli 등 ${ }^{19}$ 은 대부분 의 증례에서 교합평면은 후구치삼각융기 하방 $1 / 3$ 에 위 치함을 보고하였다. Ismail 등은 자연치열과 총의치 인 공치열을 이용하여 측모두부방사선사진 계측을 시행한 비교연구에서 양측성 균형교합을 부여한 총의치 인공치 아 배열 시, 제 2 대구치를 후구치삼각융기의 중앙 $1 / 3$ 이 나 하방 $1 / 3$ 보다는 상방 $1 / 3$ 수준에 위치하도록 변경해 야 한다고 하였다. Nissan 등 ${ }^{23}$ 은 측모두부계측학연구에 서 교합평면을 결정하기 위하여 이용하는 해부학적 구조
물(후구치삼각융기, 교합평면, Camper's plane)과 안모 형태(facial skeletal shape) 간의 관계를 조사하였는데, 안 모형태는 해부학적 구조물의 위치와는 상관관계가 없다 고 하였다. 이상과 같이 자연치열에 대한 계측 혹은 관찰 의 결과에서 후구치삼각융기는 하악 교합평면 설정기준 으로써 중요한 가치를 가지며 인공치아 배열 시 반드시 고려되는 해부학적 지표이다.

\section{후구치삼각융기 형태 분류}

하악의치를 제작하고자 할 때, 안정성을 위해 변연부 폐쇄는 필수적이며 이를 위한 중요한 해부학적 부위 중 하나가 후구치삼각융기이므로 이의 형태와 크기가 의치 의 안정성과 변연폐쇄에도 영향을 준다고 할 수 있다. 더 불어 하악 교합평면의 높이 수준을 결정하는 단계에서 도 후구치삼각융기의 높이 수준을 참고하므로 그 형태 와 크기의 다양성이 교합평면 결정단계에 영향을 미친다 고 할 수 있다. López 등 ${ }^{24}$ 은 45 명의 부분 혹은 완전무치 악 환자에서 채득된 81 개의 모형을 이용하여 후구치삼 각융기의 형태와 크기를 계측하였다. 난원형(oval), 원형 (round), 삼각형(triangular)과 같이 3가지 형태로 구분하 였고 난원형이 $53 \%$ 정도로 많고 횡적(transverse)보다 는 종적(longitudinal)으로 길며 좌우측의 크기 차이는 없 다고 하였다. 그러나, 인상채득과정이 모호하고 모형상 에서 경계를 표시하는데 있어 뚜렷하지 않으며 측정방법 을 제시하지 않은 점과 상대적으로 적은 측정대상이 한 계이다. Sharma 등 ${ }^{25}$ 은 150 명의 무치악환자만을 대상으 로 기능인상을 채득한 모형에서 후구치삼각융기 부위를 색깔로 표시한 후 이를 계측하였고, 배형/난원형(pearshaped/oval), 삼각형, 원형의 순으로 많은 빈도를 보이 고 3 가지 형태 간에 횡적이나 종적으로 차이가 있다고 하 였으며 좌우 비교 시에는 차이가 없다고 하였다. 그들의 연구는 기능인상을 채득한 최종모형에서 후구치삼각영 역을 표시하고 수평직경과 수직직경만을 구하였고, 형태 의 분류도 배형, 원형, 삼각형으로만 구분하고 난원형을 배형에 포함하였는데, 이의 뚜렷한 원인을 밝히지는 않 았다. 원형은 수평직경과 수직직경의 길이가 같아질수록 즉, 수평/수직직경비율이 1:1에 근접할수록 다른 형태와 쉽게 구별될 수 있으나 수직직경이 커질수록 난원형과 구 분이 어려워지는 까닭에 일부는 원형과의 구분도 어려웠 을 것이라 생각된다. 후구치삼각융기의 경계를 모형상에 서 표시할 때 기능인상을 채득한 최종모형을 사용한 점 
은 긍정적이긴 하지만, 계측방법에 대해 구체적인 제시가 없었다.

후구치삼각융기 하방의 골조직은 협측으로는 협근의 근섬유 일부가 부착하고 있고, 설측은 악설골근 근섬유 일부가 부착하는 이유로 골흡수에 잘 저항하기 때문에 ${ }^{6}$ 골흡수가 심한 잔존치조제를 갖는 사람에게서 조차도 후구치삼각융기는 상대적으로 안정적인 지표가 될 수 있 다고 하였다. ${ }^{5}$ 그렇지만, 이러한 주장에 대해 연조직인 후 구치삼각융기가 원래의 형태를 평생 유지할 수 있는지, 아니면 변화의 가능성이 있는지는 확실하지 않다. 후구 치삼각융기 내부에는 근섬유 뿐 아니라 선조직과 조직을 포함하고 있어 변화의 다양성이 존재한다. ${ }^{10}$ 제 3 대구치의 존재로 인해 최소한 후구치삼각융기의 전방부는 영향을 받는 부위가 될 수 있는데, 이의 이유는 제 3 대구치 발거 후에 제 3 대구치 원심에 인접한 치은유두부가 후구치삼 각융기의 전방부와 융합을 하기 때문이다. 이로 인해 형 태의 변화 가능성은 제 3 대구치 발거 이후의 시기와 연관 이 있을 수 있다고 판단되며 그 이후로는 하방의 단단한 근섬유 부착부인 피질골의 존재로 인하여 안정적일 것이 다. 따라서, 후구치삼각융기 형태의 후천적인 변화는 제 3 대구치 유무, 제 3 대구치 맹출형태, 수술 후 치유양상 등 에 의해 영향을 받는다고 할 수 있다.

\section{결론}

후구치 영역에 존재하는 후구치삼각융기는 최후방 구 치의 존재, 존재 시 발거력, 발거 후 치유과정을 통해 형 태와 크기가 달라지므로 좀 더 포괄적인 이해가 필요하 다. 인공치아 배열을 위한 교합평면 설정기준으로써 후 구치삼각융기에 관한 연구는 역사적으로 다양한 반면, 임상적인 중요성에도 불구하고 형태학적인 연구는 상대 적으로 아주 빈약하다. 계측학적 방법을 통한 형태에 대 한 내용과 빈도, 분류와 같은 임상적 가치가 부여된 연구 들이 추가적으로 필요하다.

\section{Acknowledgements}

이 논문은 2017년도 강릉원주대학교치과병원 협동임 상연구비(CR1701) 지원에 의해 수행되었음.

\section{ORCID}

Chan-Jin Park https://orcid.org/0000-0003-4734-214X Kyung-Ho Ko https://orcid.org/0000-0002-1260-8844 Yoon-Hyuk Huh https://orcid.org/0000-0003-4072-5199 Lee-Ra Cho https://orcid.org/0000-0003-3989-2870

\section{References}

1. Zarb G, Hobkirk JA, Eckert SE, Jacob RF. Prosthodontic treatment for edentulous patients. 13th ed. St. Louis; Elsevier Mosby; 2013. p. 167-8.

2. Craddock FW. Retromolar region of the mandible. J Am Dent Assoc 1953;47:453-5.

3. McCrorie JW, Hall DC. A histologic investigation of the retromolar and pear-shaped pad. Dent Pract Dent Rec 1965;15:237-9.

4. Gruber H, Solar P, Ulm C. Maxillomandibular anatomy and patterns of resorption following atrophy. Watzek G, editor. Endosseous Implants. Scientific and Clinical Aspects. Chicago; Quintessence; 1993. p. 29-62.

5. Wright CR. Evaluation of the factors necessary to develop stability in mandibular dentures. J Prosthet Dent 1966;16:414-30.

6. Pietrokovski J, Kaffe I, Arensburg B. Retromolar ridge in edentulous patients: clinical considerations. J Prosthodont 2007;16:502-6.

7. Ismail YH, Bowman JF. Position of the occlusal plane in natural and artificial teeth. J Prosthet Dent 1968;20:407-11.

8. Wright WH. Selection and arrangement of artificial teeth for complete prosthetic dentures. J Am Dent Assoc 1936;23:2291-307.

9. Martone AL, Edwards LF. Anatomy of mouth and its related structures. J Prosthet Dent 1962;12:81734.

10. Pendleton EC. The minute anatomy of the denture bearing area. J Am Dent Assoc 1934;21:488-504.

11. Worthington P, Rubenstein JE. Problems associated with the atrophic mandible. Dent Clin North Am 1998;42:129-60.

12. Sinobad D. The position of occlusal plane in dentulous subjects with various skeletal jaw relations. J Oral Rehabil 1988;15:489-98. 
13. Boucher CO. Swenson's complete dentures. 5th ed. St. Louis; CV Mosby; 1964. p. 246-51.

14. Hall WA. Important factors in adequate denture occlusion. J Prosthet Dent 1958;8:764-75.

15. Rahn AO, Heartwell CM. Textbook of complete dentures. 5th ed. Wolters Kluwer Co.; 1986. p. 352.

16. Engelmeier RL. Complete denture esthetics. Dent Clin North Am 1996;40:71-84.

17. Gupta R, Aeran H, Singh SP. Relationship of anatomical landmarks with occlusal plane. J Indian Prosthodont Soc 2009;9:142-7.

18. Lunquist DO, Luther WW. Occlusal plane determination. J Prosthet Dent 1970;23:489-98.

19. Shigli K, Chetal B, Jabade J. Validity of soft tissue landmarks in determining the occlusal plane. J Indian Prosthodont Soc 2005;5:139-45.

20. Yasaki M. Height of the occlusion rim and the interocclusal distance. J Prosthet Dent 1961;11:26-31.
21. Nagle RJ, Sears VH. Denture prosthetics. 2nd ed. St. Louis; CV Mosby; 1962. p. 134.

22. Ghosn CA, Zogheib C, Makzoumé JE. Relationship between the occlusal plane corresponding to the lateral borders of the tongue and the ala-tragus line in edentulous patients. J Contemp Dent Pract 2012;13:590-4.

23. Nissan J, Barnea E, Zaltzer C, Cardash HS. Relationship between the occlusal plane determinants and craniofacial structures. J Oral Rehabil 2003;30:587-91.

24. López FB, Suazo GI, Cantín LM, Sandoval MC. Biometrics study of the retromolar pad. Int $\mathrm{J}$ Odontostomat 2008;2:39-42.

25. Sharma A, Deep A, Siwach A, Singh M, Bhargava A, Siwach R. Assessment and evaluation of anatomic variations of retromolar pad: a cross sectional study. J Clin Diag Res 2016;10:ZC143-5. 


\section{임상적인 적용에 기반한 후구치삼각융기 형태와 분류의 포괄적인 이해}

박찬진, 고경호, 허윤혁, 조리라*

강릉원주대학교 치과대학 치과보철학교실 및 구강과학연구소

무치악 환자의 교합평면 수준을 결정할 때 후구치삼각융기는 흔하게 이용하는 해부학적 지표 중 하나로 연조직 덩어리 이며 의치의 의해 피개 되어야 한다. 후구치삼각융기의 형태는 다양성을 보이며 이는 최후방 치아 발거에 따른 치유과정 을 통해 형성되는 변화는 필연적이기 때문이다. 본 문헌고찰은 후구치삼각융기의 형태에 있어서 해부학적 관계와 임상적 인 가치를 고려하고 형태적인 분류에 관해 고찰하고자 하였다.

(구강회복응용과학지 2019;35(2) :64-71)

주요어: 후구치삼각융기; 다양성; 형태; 분류

*교신저자: 조리라

(25457)강원도 강릉시 죽헌길 7 강릉원주대학교 치과대학 치과보철학교실

Tel: 033-640-3153 | Fax: 033-640-3103 | E-mail: lila@gwnu.ac. kr

접수일: 2019년 5월 8일 | 수정일: 2019년 5월 22일 | 채택일: 2019년 5월 24일 